\title{
Exploration of Erythromycin Ribosomal Methylase Genotypes Among D+ Methicillin-resistant Staphylococcus aureus Strains in Sokoto, Nigeria
}

\author{
Sokoto, Nijerya'da D+ Metisiline Dirençli Staphylococcus aureus Kökenlerinde Eritromisin \\ Ribozomal Metilaz Genotiplerinin AraştıııIması
}

\author{
(D) Shuaibu Suleiman ADEIZA, (D) Josiah Ademola ONAOLAPO, (D) Busayo Olalekan OLAYINKA \\ Ahmadu Bello University Faculty of Pharmaceutical Sciences, Department of Pharmaceutical Microbiology, Zaria, Nigeria
}

\section{Abstract}

Introduction: Antibiotics are lifesaving compounds that have been successful for decades. However, many pathogenic bacteria are becoming resistant to them. Cross-resistance of the macrolide-lincosamide-streptogramin B (MLSB) antibiotic classes is a major cause of increased morbidity. This study appraises the phenotypic and genotypic distribution of inducible clindamycin resistance among methicillin-resistant Staphylococcus aureus (MRSA) isolates.

Materials and Methods: Erythromycin-induced resistance to clindamycin antibiotics among MRSA isolates was verified phenotypically using the Double-disk diffusion test (D-test) and genotypically by the polymerase chain reaction.

Results: All MRSA isolates were resistant to erythromycin. The prevalence of iMLSB (iMLSB: inducible macrolide-lincosamide-streptogramin B) phenotype was 23.7\% (9/38), macrolide streptogramin (MS) phenotype 47.4\% (18/38), and cMLSB (cMLS: constitutive macrolide-lincosamidestreptogramin) phenotype $28.9 \%(11 / 38)$ of the isolates. The nine isolates with the iMLSB phenotype were tested for the presence of the erythromycin ribosomal methylase (erm) gene. The ermA gene was detected in five (55.6\%) isolates, the ermB gene in two (22.2\%) isolates, and the ermC gene in two (22.2\%) isolates.

Conclusion: The erm-positive isolates expressed the iMLSB phenotype, and the ermA gene was predominant. We showed that the cMLSB phenotype was prevalent among the MRSA isolates, signifying the possibility of achieving a good therapeutic outcome when clindamycin is used. The observed distribution of the erm gene explored here gives credence to the adequacy of the D-test in monitoring and testing for potential clindamycin treatment failures.

Keywords: ORSA, cefoxitine-resistant Staphylococcus aureus, linezolid, molecular epidemiology, oxacillin-resistant Staphylococcus aureus

\section{Öz}

Giriş: Antibiyotikler, onlarca yıldır hayat kurtaran önemli bileşiklerdir. Ancak pek çok patojenik bakteri antibiyotiklere direnç kazanmaktadır. Makrolid-linkozamid-streptogramin B (MLSB) antibiyotik sınıflarında çapraz direnç morbidite artışına neden olabilmektedir. Bu çalışmada, metisilindirençli Staphylococcus aureus (MRSA) izolatlarında indüklenebilir klindamisin direncinin fenotipik ve genotipik dağılımı değerlendirilmektedir.

Gereç ve Yöntem: MRSA kökenlerinde eritromisin ile indüklenen klindamisin direnci, fenotipik olarak D-testi yoluyla ve genotipik olarak polimeraz zincir reaksiyonu ile doğrulandı.

Bulgular: Tüm MRSA izolatları eritromisine dirençliydi. İzolatlarda indüklenebilir iMLSB fenotipi (iMLSB: indüklenebilir makrolid, linkozamid streptogramin B) prevalansı \%23,7 (9/38), makrolid streptogramin (MS) fenotipi prevalansı \%47,4 (18/38) ve cMLSB (cMLSB: yapısal (constitutive)

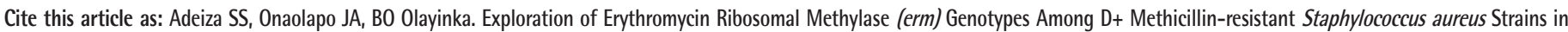
Sokoto, Nigeria. Mediterr J Infect Microb Antimicrob. 2019;8:39. 
makrolid linkozamid streptogramin B) fenotipi prevalansı \%28,9 (11/38) idi. iMLSB fenotipi gösteren dokuz köken, erm genleri açısından test edildi. ermA geni $5(\% 55,6)$ izolatta, ermB geni $2(\% 22,2)$ izolatta ve ermC geni $2(\% 22,2)$ izolatta tespit edildi.

Sonuç: erm pozitif izolatlar iMLSB fenotipi göstermekteydi ve ermA geni baskındı. MRSA kökenlerinde cMLSB fenotipinin yaygın olduğunu ve klindamisin ile tedavide başarı sağlanabileceğini gösterdik. Bu çalışmada araştırılan erm genlerinin dağılımı, klindamisin tedavisinin başarısız olduğu olguların izlenmesinde D-testinin yeterliliğini göstermektedir.

Anahtar Kelimeler: ORSA, sefoksitin dirençli Staphylococcus aureus, linezolid, moleküler epidemiyoloji, oksasiline dirençli Staphylococcus aureus

\section{Introduction}

Antibioticsare lifesaving compounds that have been successful for decades. However, almost all pathogenic bacteria are becoming resistant to them ${ }^{[1]}$. The frequency of infections due to antibioticresistant bacterial strains is on the rise ${ }^{[2]}$. Staphylococcus aureus is among the most prevalent nosocomial pathogen ${ }^{[3]}$. There is documentation on the treatment of methicillin-resistant Staphylococcus aureus (MRSA) skin infections with macrolidelincosamide-streptogramin B (MLSB) antibiotics ${ }^{[4]}$. Sometimes resistance to MRSA therapy with erythromycin (macrolide) may extend to clindamycin (lincosamide) and streptogramin B drug classes. Earlier literature reported induced resistance with erythromycin ribosomal methylase $(\mathrm{erm})$ via the modification of the common drug binding sites of the three drug classes on the $23 \mathrm{~S} r R N A^{[5]}$. The erm gene codes for the enzyme that alters the binding site for MLSB antibiotics causing cross-resistance to multiple antibiotic classes and thus increases the risk of treatment failure ${ }^{[6]}$. The ermA gene is located on transposon Tn554/Tn6133, ermB on Tn917/Tn551, and ermC on smaller plasmids ${ }^{[7]}$. There are ten different erm $(A, B, C, F, G, O, T, Y$, 33 and 43 ) genotypes proficient with erythromycin resistance (ER) but the erm $A, B$, and $C$ genotypes confer resistance to erythromycin in $94 \%$ to $98 \%$ of ER staphylococcal strains ${ }^{[7,8]}$. MLSB resistance can be inducible (erythromycin-resistant and clindamycin susceptible) or constitutive (resistant to all MLSB antibiotics) ${ }^{[9]}$. The Double-disk diffusion test (D-test) is used to detect erythromycin-inducible clindamycin resistance. Improper screening for clindamycin resistance in IMLSB MRSA phenotypes increases the risk of treatment failure, which may result in increased morbidity and mortality ${ }^{[10]}$. This study appraises the phenotypic and genotypic distribution of inducible clindamycin resistance among MRSA isolates.

\section{Materials and Methods}

This study was carried out in Sokoto State, at the extreme north-west of Nigeria, between longitudes $4^{\circ} 8^{1}$ and $6^{\circ} 54^{1}$ and latitude $12^{\circ} \mathrm{N}$ and $13^{\circ} 58^{1} \mathrm{~N}$. The population of the state is about 5.4 million $^{[11]}$. It shares a border with the Republic of Niger and covers a land area of $32,000 \mathrm{~km}^{2}$. The Hausa and Fulani ethnic groups are the principal inhabitants of the state ${ }^{[11]}$.

During the six-month study, from February to July 2018, 38 phenotypically confirmed MRSA strains that were isolated from the nasal swabs of consenting participants (eight inpatients, 11 outpatients, and 19 healthcare workers) after receipt of ethical approval from the review board of Sokoto State ministry of health under approval number SMH/1580/V.IV. Resistance to methicillin by the isolates was confirmed by the oxacillin resistance screening agar base test ${ }^{[12,13]}$.

Double-disk diffusion/approximation test (D-test) was used to determine resistant phenotypes of the MRSA isolates to MLSB as specified by the Clinical and Laboratory Standards Institute ${ }^{[14]}$; erythromycin $(15 \mu \mathrm{g})$ and clindamycin $(2 \mu \mathrm{g})$ disks (Oxoid"', Basingstoke, UK) were placed side by side at a distance of $12 \mathrm{~mm}$ on a pre-inoculated ( $0.5 \mathrm{McF}$ (arland standard) Mueller Hinton agar plates. The plates were incubated at $35{ }^{\circ} \mathrm{C}$ for 16 to 18 hours. Isolates that were resistant to erythromycin, clindamycin sensitive, and formed a D-shaped zone of inhibition around clindamycin were noted as inducible phenotypes of MLS resistance (iMLS). Furthermore, the presence of the constitutive type of MLS resistance (CMLSB) was evidenced by isolates that showed resistance to erythromycin and clindamycin ${ }^{[15]}$. Finally, MRSA isolates that displayed resistance to erythromycin and sensitivity to clindamycin with no D-shaped zone were considered to have the MS (macrolide streptogramin) phenotype ${ }^{[16]}$.

The standard disk diffusion method was used to determine the resistant profiles of D+ isolates according to the criteria of the Clinical Laboratory Standard Institute ${ }^{[14]}$ using WHONET 2018 software. The antibiotics used were clindamycin $(2 \mu \mathrm{g})$, erythromycin $(15 \mu \mathrm{g})$, ceftazidime $(30 \mu \mathrm{g})$, trimethoprim/ sulfamethoxazole $(1.25 / 23.75 \mu \mathrm{g})$, linezolid $(30 \mu \mathrm{g})$, tetracycline $(30 \mu \mathrm{g})$, cefoxitin $(30 \mu \mathrm{g})$, and levofloxacin $(5 \mu \mathrm{g})$ (Oxoid"', Basingstoke, UK).

The genomic DNA of bacterial isolates was extracted using Qiagen" Kit (Hilden, Germany) as described by the manufacturer ${ }^{[17]}$. The primer sequences used in this study were calculated using Primer3Plus ${ }^{\otimes[18]}$ on a matrix of oligonucleotide sequences obtained from GenBank/NCBI and sent for production (Inqaba Biotec"', South Africa). The primer sequences used are shown in Table 1.

The products of polymerase chain reaction (PCR) amplification were electrophoresed on a 1.5\% agarose gel pre-stained with ethidium bromide and visualized in a Bio-Rad"' gel (Bio-rad laboratories, Milan, Italy) documentation device using an UV trans-illuminator. 
A multiplex PCR assay targeting the erm (inducible clindamycin resistance) gene was performed under the following conditions: The PCR cocktail contained $1 \mu \mathrm{l}$ of each primer pair $(3 \mu \mathrm{l}), 3$ $\mu \mathrm{l}$ molecular grade water, $4 \mu \mathrm{l}$ of DNA template, $12.5 \mu \mathrm{l}$ of Qiagen master mix, and $2.5 \mu \mathrm{l}$ of Q-reagent totaling a $25 \mu \mathrm{l}$ reaction mixture. The PCR process (Applied BioSystems 9700 thermocycler) was started with an initial denaturation step (94 ${ }^{\circ} \mathrm{C}$ for $5 \mathrm{~min}$ ) after which it was trailed by another denaturation process (for 30 cycles at $94^{\circ} \mathrm{C}$ for $30 \mathrm{~s}$ ), followed by an annealing step $\left(55^{\circ} \mathrm{C}\right.$ for $\left.30 \mathrm{~s}\right)$, an extension step $\left(72{ }^{\circ} \mathrm{C}\right.$ for $\left.30 \mathrm{~s}\right)$, and a final extension $\left(72{ }^{\circ} \mathrm{C} \text { for } 7 \mathrm{~min}\right)^{[19]}$.

\section{Statistical Analysis}

Statistical analysis was conducted on the results obtained using SAS ${ }^{\circledast}$ software, version 9.4 (SAS Institute Inc., Cary, North Carolina). Descriptive statistics were performed on the presence or absence of erm $A, B$, and $C$ genes.

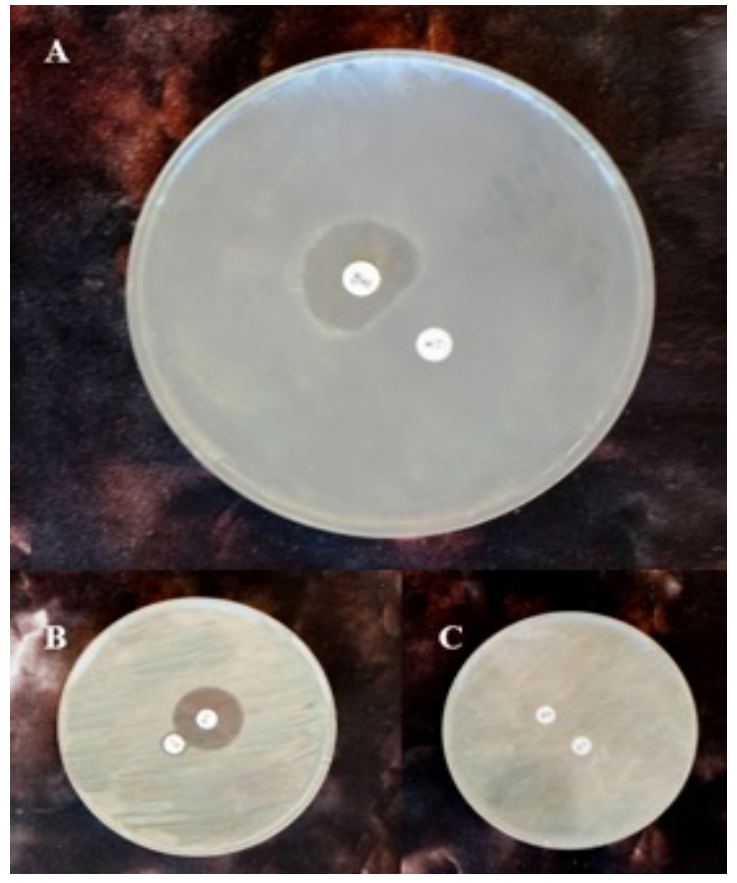

Figure 1. Mueller Hinton agar plates demonstrating $(A)$ inducible macrolide-lincosamide-streptogramin B phenotype, (B) macrolide streptogramin-MS phenotype, and (C) constitutive macrolidelincosamide-streptogramin phenotype

\section{Results}

In this study, MRSA isolates showed 100\% resistance to cefoxitin, ceftazidime, and erythromycin. They were also resistant to tetracycline (84.2\%), levofloxacin (55.3\%), clindamycin (52.6\%), linezolid (44.7\%), and trimethoprim/sulfamethoxazole (39.5\%).

Figure 1 depicts the D-test demonstrating: (A) The formation of the $\mathrm{D}$-zone around clindamycin due to erythromycin resistance, (B) the MS phenotype, and (C) the cMLSB phenotype. All MRSA isolates were resistant to erythromycin. The prevalence of the iMLSB phenotype (Figure 2A) was 23.7\% (9/38), the MS phenotype $47.4 \%$ (18/38), and the cMLSB phenotype $28.9 \%$ $(11 / 38)$ among the study isolates. Nine isolates with the iMLSB phenotype were tested for the presence of the erm gene (Figures $2 B$ and 3). The ermA gene was detected in five (55.6\%) isolates, the ermB gene in two (22.2\%) isolates, and the erm $C$ gene in two $(22.2 \%)$ isolates.

Figure 4 displays the resistance profiles of iMLSB positive isolates. The isolates were profiled as being predominantly resistant to
$\mathbf{A}$

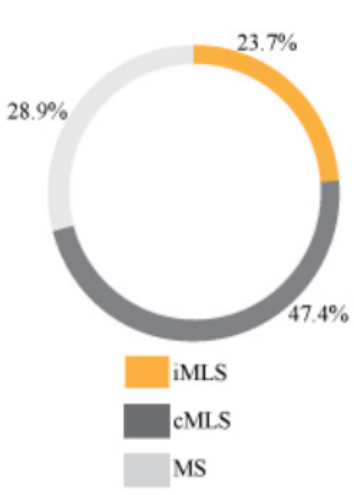

B

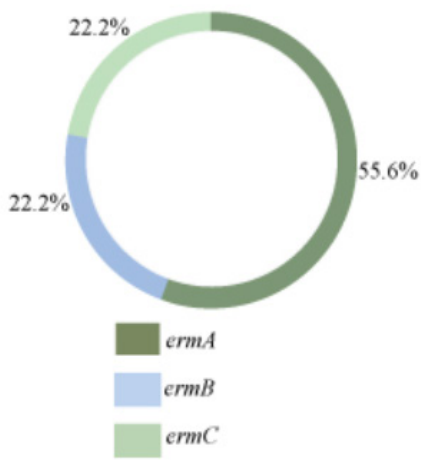

Figure 2. Percentage distribution of (A) clindamycin resistance phenotypes and (B) genotypes among methicillin-resistant Staphylococcus aureus isolates

iMLS: inducible macrolide-lincosamide-streptogramin B phenotype, MS:macrolide streptogramin phenotype cMLS: constitutive macrolide-lincosamidestreptogramin phenotype erm: erythromycin resistance methylase

\begin{tabular}{|c|c|c|c|c|c|}
\hline Primer & & Sequence $\left(5^{\prime}-->3^{\prime}\right)$ & Product & $\operatorname{Temp}\left({ }^{\circ} \mathrm{C}\right)$ & Accession \\
\hline ermA & $\mathrm{F}$ & GCCTGACПTCAAAGGTAATC & $421 b p$ & $57.1^{\circ} \mathrm{C}$ & AF466412 \\
\hline \multirow[t]{2}{*}{$\mathrm{erm} B$} & $\mathrm{~F}$ & GCCATGCGTCTGACATCTAT & $359 b p$ & $58.7^{\circ} \mathrm{C}$ & KP823590 \\
\hline & $\mathrm{R}$ & CTGTGGTATGGCGGGTAAGT & - & - & - \\
\hline
\end{tabular}


clindamycin, erythromycin, cefoxitin, ceftazidime, tetracycline, and levofloxacin. However, 40\% (2/5) of isolates with ermA genotypes were linezolid-resistant phenotypically. Resistance to trimethoprim/sulfamethoxazole was also evidenced in only 2/9 isolates.

\section{Discussion}

The present study showed that erythromycin, cefoxitin, and ceftazidime were the antimicrobial agents with the highest antibiotic resistance rates. This finding is similar to reports by others ${ }^{[13,20,21]}$. Erythromycin is an inexpensive and available antimicrobial agent in Nigeria ${ }^{[15]}$. Its prophylactic and therapeutic use in healthcare and community settings may establish a

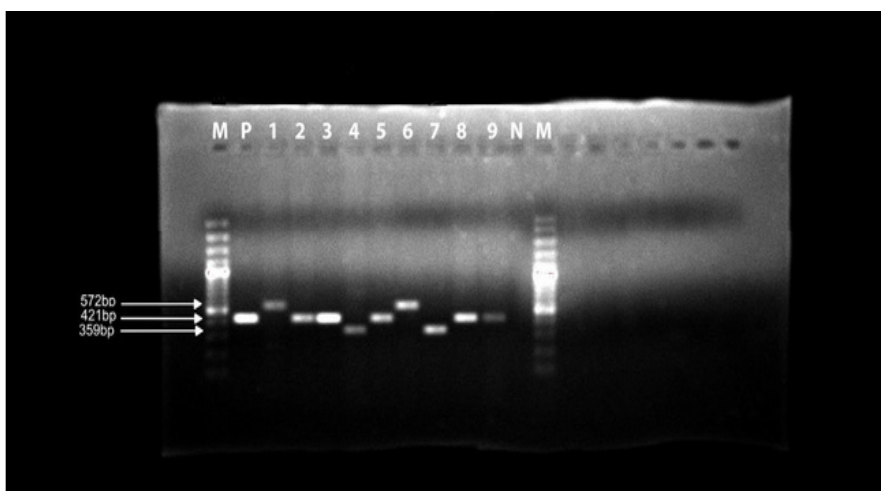

Figure 3. Electrophoretogram of multiplex polymerase chain reaction for erythromycin resistance methylase (erm) genes for nine inducible macrolide-lincosamide-streptogramin B (iMLSB) positive isolates. In the Figure: ermA positive (421 bp), ermB positive (359 bp), erm C positive (572 bp). M is $100 \mathrm{bp}+$ DNA ladder, $\mathrm{P}$ and $\mathrm{N}$ positive and negative controls. Lane 1 and $13=100 \mathrm{bp}+$ DNA ladder, Lane 2=S. aureus ATCC 25923 (positive control), Lane 3-11=MLSB positive isolates, and Lane 12=negative control (nuclease-free water)

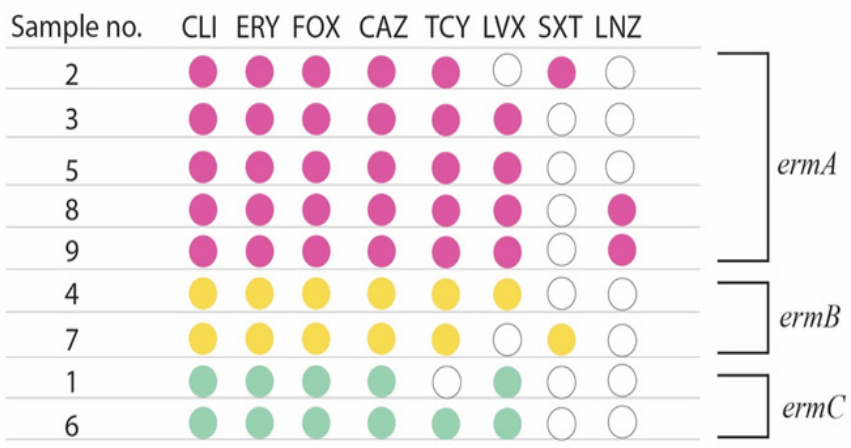

Figure 4. Resistance profile of inducible macrolide-lincosamidestreptogramin B positive isolates and their corresponding genotypes. The antibiotic resistance profiles for the erm genotypes are displayed in pink (ermA), yellow (ermB), and green (ermC).

CLI: Clindamycin, CAZ: Ceftazidime, SXT: Trimethoprim/sulfamethoxazole, LNZ: Linezolid, CAZ: Cefoxitin $(30 \mu \mathrm{g})$, LVX: Levofloxacin, TCY: Tetracycline, ERY: Erythromycin, erm: erythromycin resistance methylase persistent selective pressure favoring the evolution of resistant strains ${ }^{[22]}$. Further, widespread availability of antibiotics favors mutational events that confer resistance with little or no fitness cost like compensatory mutations, genetic co-selection, genetic plasticity, and others ${ }^{[22,23]}$.

Clindamycin is a bacteriostatic antimicrobial with good tissue penetration. Nevertheless, reports of the rise in MRSA resistance has limited its clinical application. Experts use clindamycin monotherapy in the management of mild to moderate MRSA infections $^{[24]}$ or in combination therapy with rifampicin ${ }^{[24]}$, vancomycin $^{[25]}$, and ceftaroline ${ }^{[26]}$ when the induction of resistance is suspected. Our study revealed that the prevalence of inducible clindamycin resistance among 38 MRSA isolates was $23.7 \%$, which is less than the $28.6 \%$ (2/7 isolates) and $75 \%$ (3/4 isolates) extracted from the data buried within the source files $^{[27,15]}$. Another study ${ }^{[28]}$ in Iran reported a lower rate of iMLSB of $10.7 \%$ (9/84). The MS phenotype of $28.9 \%$ found in this study is also higher compared with the $14.3 \%$ reported by others ${ }^{[27]}$. We found the constitutive (cMLSB) resistance phenotype in this study to be $47.9 \%$, which is higher than the $35.7 \%(30 / 84$ isolates) reported by Goudarzi et al. ${ }^{[28]}$, and the $28.6 \%(2 / 7$ isolates) reported by Gadekar et al. ${ }^{[27]}$. Our result is not surprising, as many studies have associated a large percentage of cMLSB with MRSA isolates than MSSA isolates ${ }^{[29]}$. The majority of the MRSA isolates in this study were D-test negative, suggesting that if a large percentage (47.9\%) of our tested isolates were tested with clindamycin, then treatment would be effective. The large difference in resistance rates observed in this study might be because of various factors, including differences in sample populations, phenotypic methods, geographical distributions, and the diversity of the circulating MRSA strains ${ }^{[30]}$.

Similar with other studies ${ }^{[31]}$, the ermA gene was the most prevalent (55.6\%) among iMLSB isolates in the current study. None of the studied MRSA strains harbored the double erm gene. The differences in ermA prevalence relative to other studies may be because of geographic inconsistency among the iMLSB resistance phenotypes ${ }^{[19]}$.

The MLSB profile observed in this study may have occurred due to the modification (methylation) of the common drug binding sites of the three drug classes on the $23 S$ rRNA encoded by the erm gene ${ }^{[32]}$. This resistance mechanism provokes drug binding to translational attenuator sequences upstream, which subsequently leads to a change in the mRNA secondary structure. It is also possible for spontaneous mutations to occur and transform iMLSB strains to the cMLSB phenotype without a genetic inducer ${ }^{[20]}$.

All nine D+ MRSA isolates in this study were multidrugresistant (MDR) besides being methicillin-resistant, indicating 
the presence of other genes not evaluated in this study. The documented MDR profile may have arisen because erm is a multidrug resistance gene that mediates co-resistance to multiple classes of antibiotics ${ }^{[33]}$. Based on this premise, the erm-carrying plasmid may recombine or integrate with another multi-resistance plasmid like the tetracycline resistance gene (tetK) carrying plasmid resulting in plasmid modifications that may broaden the MDR spectrum when expressed ${ }^{[7]}$.

A major limitation of this study was that we did not perform further molecular analysis and DNA sequencing of the amplicons to verify the relationship between the resistance mechanisms and the antibiotic susceptibility test results (e.g., linezolid resistance) further by comparative genome analysis.

\section{Conclusion}

In our study, the erm-positive isolates expressed the iMLSB phenotype, and the ermA gene was predominant. We showed that the cMLSB phenotype was prevalent among the MRSA isolates, signifying the possibility of achieving a good therapeutic outcome when clindamycin is used. The observed distribution of the erm gene explored here gives credence to the adequacy of the D-test in monitoring and testing for potential clindamycin treatment failures.

\section{Acknowledgements}

The authors of this paper express their appreciation to Mr. Abdulmalik Bello Shuaibu of the Molecular Biology Laboratory of the Department of Veterinary Microbiology Usmanu Danfodiyo University Sokoto for his stanch backing. We also like to thank Mrs. Halima Salihu for her admirable proofreading role.

\section{Ethics}

Ethics Committee Approval: The study protocol was approved by the Ethical Review Board of Sokoto State Ministry of Health (reference number: SMH/1580/V.IV.).

Informed Consent: Informed consent was obtained from each study participant after assurance of anonymity.

Peer-review: Externally and internally peer-reviewed.

\section{Authorship Contributions}

Concept: J.A.O., B.O.O., Design: J.A.O., B.O.O., S.S.A., Data Collection or Processing: S.S.A., Analysis or Interpretation: S.S.A., Literature Search: S.S.A., Writing: S.S.A., J.A.O., B.O.O.

Conflict of Interest: No conflict of interest was declared by the authors.

Financial Disclosure: The authors declared that this study received no financial support.

\section{References}

1. Carder M. The Rise in Antibiotic Resistance: A Cause for Concern. Microreviews in Cell and Molecular Biology. 2019;5:1-2.

2. MacLean RC, Millan AS. The evolution of antibiotic resistance. Science. 2019;365:1082-3.

3. Jackson KA, Gokhale RH, Nadle J, Ray SM, Dumyati G, Schaffner W, Ham DC, Magill SS, Lynfield R, See I. Public health importance of invasive methicillin-sensitive Staphylococcus aureus infections-surveillance in eight US counties, 2016. Clin Infect Dis. 2020;70:1021-8.

4. Petinaki E, Papagiannitsis K. Resistance of staphylococci to macrolideslincosamides-streptogramins B (MLSB): epidemiology and mechanisms of resistance. In: Staphylococcus aureus. Intech Open. 2018:117-33. Available from: https://www.intechopen.com/books/-i-staphylococcus-aureus-i-/ resistance-of-staphylococci-to-macrolides-lincosamides-streptograminsb-mlsb-epidemiology-and-mechan

5. Sarrou S, Malli E, Tsilipounidaki K, Florou Z, Medvecky M, Skoulakis A, Hrabak J, Papagiannitsis CC, Petinaki E. MLSB-resistant Staphylococcus aureus in Central Greece: rate of resistance and molecular characterization. Microbial Drug Resistance. 2019;25:543-50.

6. Yao W, Xu G, Li D, Bai B, Wang H, Cheng H, Zheng J, Sun X, Lin Z, Deng 0 . Staphylococcus aureus with an erm-mediated constitutive macrolide-lincosamide-streptogramin B resistance phenotype has reduced susceptibility to the new ketolide, solithromycin. BMC Infect Dis. 2019;19:175.

7. Wendlandt S, Shen J, Kadlec K, Wang Y, Li B, Zhang W-J, Febler AT, Wu C, Schwarz $\mathrm{S}$. Multidrug resistance genes in staphylococci from animals that confer resistance to critically and highly important antimicrobial agents in human medicine. Trends Microbiol. 2015;23:44-54.

8. Nawaz M, Khan S, Khan A, Khambaty F, Cermiglia C. Comparative molecular analysis of erythromycin-resistance determinants in staphylococcal isolates of poultry and human origin. Mol Cell Probes. 2000;14:311-9.

9. Szemraj M, Czekaj T, Kalisz J, Szewczyk EM. Differences in distribution of MLS antibiotics resistance genes in clinical isolates of staphylococci belonging to species: S. epidermidis, S. hominis, S. haemolyticus, S. simulans and S. warneri. BMC Microbiol. 2019;19:124.

10. Mama M, Aklilu A, Misgna K, Tadesse M, Alemayehu E. Methicillin-and Inducible Clindamycin-Resistant Staphylococcus aureus among Patients with Wound Infection Attending Arba Minch Hospital, South Ethiopia. Int J Microbiol. 2019;2019:2965490.

11. Sokoto (State, Nigeria) - Population Statistics, Charts, Map and Location. Last accessed date: 2019 Nov 1. Available from: https://citypopulation.de/ php/nigeria-admin.php?adm1id=NGA034

12. El-Mokhtar MA, Hetta HF. Ambulance vehicles as a source of multidrugresistant infections: a multicenter study in Assiut City, Egypt. Infect Drug Resist. 2018;11:587-94.

13. Kwoji ID, Jauro S, Musa JA, Lekko YM, Salihu SI, Danchuwa HA. Phenotypic detection of methicillin-resistant Staphylococcus aureus in village chickens from poultry markets in Maiduguri, Nigeria. J Adv Vet Anim Res. 2019;6:163-7.

14. Clinical \& Laboratory Standards Institute (CLSI). CLSI Microbiology: 2018 AST Packages. Last accessed date: 2019 Sep 23. Available from: https://clsi. org/global-training-old/2018-ast-packages/

15. Godwin Nwokah E. Inducible-Clindamycin Resistance in Staphylococcus aureus isolates in Rivers State, Nigeria. AJCEM. 2016;4:50-5.

16. Siberry GK, Tekle T, Carroll K, Dick J. Failure of clindamycin treatment of methicillin-resistant Staphylococcus aureus expressing inducible clindamycin resistance in vitro. Clin Infect Dis. 2003;37:1257-60. 
17. Bien H. QlAgen DNeasy Blood \& Tissue kit, cultured cells. Last Accessed date: 2015. Available from: https://www.protocols.io/view/QIAgen-DNeasyBlood-Tissue-kit-cultured-cells-dsz6f5

18. Untergasser $A$, Nijveen $H$, Rao $X$, Bisseling $T$, Geurts $R$, Leunissen JA. Primer3Plus, an enhanced web interface to Primer3. Nucleic Acids Res. 2007;35(Web Server issue):W71-4.

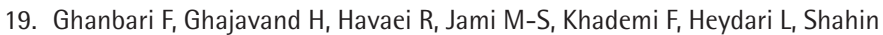
M, Havaei S. Distribution of erm genes among Staphylococcus aureus isolates with inducible resistance to clindamycin in Isfahan, Iran. Adv Biomed Res. 2016;5:62.

20. Kaur DC, Chate SS. Study of Antibiotic Resistance Pattern in Methicillin Resistant Staphylococcus aureus with Special Reference to Newer Antibiotic. J Glob Infect Dis. 2015;7:78-84.

21. Ifeanyichukwu I, Chika E, Emmanuel N, Anthonia O, Ngozi A, Esther UI. Community acquired methicillin resistant Staphylococcus aureus (caMRSA) carriage amongst tertiary school students. AJST. 2015;2:18-21.

22. Gill J. Fitness costs of methicillin resistance in Staphylococcus aureus. Access Microbiology. 2019;1:62-73.

23. Dotel R, Tong SYC, Bowen A, Nelson JN, O'Sullivan MVN, Campbell AJ, McMullan BJ, Britton PN, Francis JR, Eisen DP, Robinson O, Manning L, Davis JS. CASSETE-clindamycin adjunctive therapy for severe Staphylococcus aureus treatment evaluation: study protocol for a randomised controlled trial. Trials. 2019;20:353.

24. Kim BN, Kim ES, Oh MD. Oral antibiotic treatment of staphylococcal bone and joint infections in adults. J Antimicrob Chemother. 2014;69:309-22.

25. Wargo KA, McCreary EK, English TM. Vancomycin combined with clindamycin for the treatment of acute bacterial skin and skin-structure infections. Clin Infect Dis. 2015;61:1148-54.
26. Varada NL, Sakoulas G, Lei LR, Chua J. Agranulocytosis with ceftaroline high-dose monotherapy or combination therapy with clindamycin. Pharmacotherapy. 2015;35:608-12.

27. Gadekar D, Damle A. Detection of inducible clindamycin resistance in staphylococcal isolates from chronic suppurative otitis media. IJSR. 2019;8.

28. Goudarzi M, Eslami G, Rezaee R, Heidary M, Khoshnood S, Sajadi Nia R. Clonal dissemination of Staphylococcus aureus isolates causing nosocomial infections, Tehran, Iran. Iran J Basic Med Sci. 2019;22:238-45.

29. Rajak KC, Poddar CK, Kumar R, Jha AK. Inducible clindamycin resistant Staphylococcus aureus isolates from tertiary care hospital, Bettiah, India. J Evolution Med Dent Sci. 2018;7:3984-90.

30. Manandhar S, Singh A, Varma A, Pandey S, Shrivastava N. Biofilm Producing Clinical Staphylococcus aureus Isolates Augmented Prevalence of Antibiotic Resistant Cases in Tertiary Care Hospitals of Nepal. Front Microbiol. 2018; 9: 2749 .

31. Coutinho V de LS, Paiva RM, Reiter KC, de-Paris F, Barth AL, Machado ABMP. Distribution of erm genes and low prevalence of inducible resistance to clindamycin among staphylococci isolates. Braz J Infect Dis. 2010;14:564-8.

32. Lewis JS, Jorgensen JH. Inducible Clindamycin Resistance in Staphylococci: Should Clinicians and Microbiologists be Concerned? Clin Infect Dis. 2005;40:280-5.

33. Magi G, Marini E, Facinelli B. Antimicrobial activity of essential oils and carvacrol, and synergy of carvacrol and erythromycin, against clinical, erythromycin-resistant Group A Streptococci. Front Microbiol. 2015;6. 